\title{
An evidence-based toolkit to support grading of pre-registration midwifery practice
}

\section{Way, S}

http://hdl.handle.net/10026.1/13774

10.12968/bjom.2019.27.4.251

British Journal of Midwifery

Mark Allen Healthcare

All content in PEARL is protected by copyright law. Author manuscripts are made available in accordance with publisher policies. Please cite only the published version using the details provided on the item record or document. In the absence of an open licence (e.g. Creative Commons), permissions for further reuse of content should be sought from the publisher or author. 


\title{
An evidence-based toolkit to support grading of pre-registration midwifery practice
}

Way, S., Fisher, M. and Chenery-Morris, S., 2019. An evidence-based toolkit to support grading of pre-registration midwifery practice. British Journal of Midwifery, 27(4), p251-257 https://doi.org/10.12968/bjom.2019.27.4.251

Review: This article was subject to double-blind peer review and accepted for publication on 27 February 2019

\begin{abstract}
Grading of practice has been incorporated into the United Kingdom (UK) Nursing and Midwifery Council's midwifery education standards since 2009. The literature identifies that grading practice can be fraught with challenges not least related to subjectivity, inconsistency, lack of transparency and grade inflation. An established group of UK-wide, lead midwife educators recognised these challenges and through completing a three phase project, developed an evidence-based Practice Assessment Toolkit which aims to facilitate consistent, robust and objective grading of student practice. It is suggested that this toolkit may be useful to those developing practice assessment documentation or writing evidence to reflect a student's progress and achievement in practice.
\end{abstract}

\section{Key points}

1. Midwifery practice assessment documents used across the UK Higher Education Institutions are not always easy to interpret and lack parity and consistency.

2. Lead midwife educators across the UK took a strategic approach to address the challenges being attributed to grading practice.

3. Eleven core principles for grading midwifery practice have been developed that aid clarity, fairness and robustness for the student and the midwife confirming the student's performance.

4. An evidence-based Practice Assessment Toolkit has been developed with particular relevance for to those supervising students on a daily basis when writing evidence to inform summative assessment of their progress and achievement.

\section{Introduction}

It is well documented (Heaslip and Scammell, 2012; Bennett and McGowan, 2014) that grading practice is not an easy task and can be open to subjectivity, ambiguity, confusion and grade inflation (Donaldson and Gray, 2012). As midwives we have a responsibility to support and educate student midwives in practice (NMC, 2018a). For some that may include making a graded assessment of their practice (NMC, 2009), but for all midwives, there will be the need to contribute measurable evidence which focuses on the student's performance during their period of 'practice supervision' (NMC, 2018b). This paper explores some of the specific outcomes of a three phase project that led to the development of a Practice Assessment Toolkit which may be used as a guide when developing practice assessment documents and to assist those writing evidence of student progress and assessment (AUTHORS, 2018). A key emphasis of the toolkit is that "student assessments are evidence based, robust and objective" (NMC, 2018b:9).

\section{Background}

The UK-wide Lead Midwife for Education (LME) Executive, is a national group of senior midwife educationalists from all Higher Education Institutions (HEls) across the United Kingdom (UK) that deliver midwifery programmes leading to registration on the Nursing and Midwifery Council (NMC) register. The group were aware early on of the growing issues attributed to grading practice and challenges that midwives often faced when making a graded assessment of a student's performance. Lead midwives for education were ideally 
placed and wanted to take the lead in addressing the issues at a strategic level in order to make a difference for practitioners, students and academics alike. Ensuring the assessment of a student's practice in a robust and consistent way was seen to be crucial in providing safe and effective care that protects women and babies. A working group of interested LMEs was established who embarked on a three phase project (Figure 1) to firstly undertake a scoping exercise of processes and views on current approaches to grading midwifery practice (AUTHORS, 2017a); secondly to identify a set of core principles for grading of midwifery practice (AUTHORS, 2017b), and finally to develop a UK-wide, generic framework for grading midwifery practice (AUTHORS, 2019). It was felt that this action was timely as the NMC were beginning to review the pre-registration midwifery education standards (NMC, 2009) and the outcomes achieved from the project could therefore provide an evidence base for best practice in terms of assessing the knowledge, skills and behaviour of students in the clinical environment.

Figure 1: Three phases of the project

Midwives practising in the UK will be aware of the newly published NMC standards, which set out what the NMC expects for the learning, support and supervision of students in the practice environment as well as how students are assessed for theory and practice. These standards replace the role of the mentor and sign-off mentor (NMC, 2008) with that of practice supervisor, practice assessor and academic assessor (NMC, 2018b).

The new standards resulted from a major review by the NMC of their education standards to ensure they were future proofed and fit for purpose (NMC 2018b, NMC 2018c). A practice supervisor supports and supervises midwifery students in the practice learning environment and may not be a midwife. For example, the practice supervisor may be a paediatric nurse if the student midwife has a placement in the neonatal intensive care unit. However, the practice assessor is a clinical midwife who makes and records objective, evidenced-based assessments on conduct, proficiency and achievement, so it is important that the practice supervisor can document clear and easily understood evidence detailing the student's progress so the practice assessor can make this judgement. An academic assessor is a midwife academic who again makes and records objective, evidenced-based assessments on conduct, proficiency and achievement but also recommends progression (NMC, 2018b). The term "sign-off mentor" is used in this paper to reflect the period during which the study was undertaken, but can equally be applied to these new roles and principles.

\section{The evidence base supporting the toolkit development}

Phase 1: How was practice currently being assessed? 
The first phase comprised of a descriptive, evaluative survey, which aimed to determine the variety of ways practice was being assessed, the tools that were being used and the views of practitioners using the tools (AUTHORS, 2017a). A response rate of $73 \%$ was achieved comprising of 40 of the $55 \mathrm{HEls}$ represented by the participating LMEs. The results confirmed that there was a significant lack of parity in the process of grading practice. Table 1 identifies some of the similarities and differences under six emerging themes.

\begin{tabular}{|l|l|l|}
\hline Themes & Similarities & Differences \\
\hline People & $\begin{array}{l}\text { Mentors; sign-off } \\
\text { mentors; lecturers }\end{array}$ & $\begin{array}{l}\text { Supervisor of midwives; student self- } \\
\text { assessment }\end{array}$ \\
\hline Process & $\begin{array}{l}\text { Every university had a } \\
\text { process but there was } \\
\text { limited similarity. }\end{array}$ & $\begin{array}{l}\text { Graded by sign off mentor only; } \\
\text { qualitative comments by mentor which } \\
\text { were then graded by lecturer; moderated } \\
\text { by lecturer; tripartite meeting; written work } \\
\text { graded. }\end{array}$ \\
\hline Point of course & $\begin{array}{l}\text { Graded in final week of } \\
\text { placement }\end{array}$ & $\begin{array}{l}\text { Range of assessment times throughout } \\
\text { the year; continuous assessment; } \\
\text { academic level 5 and 6 only }\end{array}$ \\
\hline Package (tool) & $\begin{array}{l}\text { Two regional } \\
\text { assessment documents }\end{array}$ & $\begin{array}{l}\text { Novice to expert framework (Benner } \\
\text { 1984); Steinaker and Bell's experiential } \\
\text { taxonomy (1979); NMC Essential Skills } \\
\text { Clusters (NMC 2009); NMC domain;; } \\
\text { knowledge, skills and attitudes (NMC } \\
\text { 2009); Department of Health 6Cs (NHS } \\
\text { Commissioning Board 2012). }\end{array}$ \\
\hline Pass mark & $\begin{array}{l}\text { If one element of } \\
\text { practice did not pass, } \\
\text { the whole assessment } \\
\text { failed. }\end{array}$ & $\begin{array}{l}\text { Percentage categories (40\%, 50\%); } \\
\text { pass/refer; five or six descriptors ranging } \\
\text { from refer to excellent; A-F and AA-FF; } \\
\text { formulaic calculation to convert } \\
\text { descriptors into numeric marks. }\end{array}$ \\
\hline Portfolio & $\begin{array}{l}\text { Not every university } \\
\text { used a portfolio as part } \\
\text { of the assessment of } \\
\text { practice so limited } \\
\text { similarity }\end{array}$ & $\begin{array}{l}\text { Universities used a variety of portfolios; } \\
\text { reflective accounts; OSCE; viva voce; } \\
\text { other assessments rather than solely } \\
\text { clinical practice to grade students. }\end{array}$ \\
\hline
\end{tabular}

Table 1: Key similarities and differences in how midwifery practice is currently graded across the UK.

Lead midwives for education commented that clinicians were positive, identifying that their contribution to grading practice made them feel valued and that they had a responsibility as 'gate keepers' to the profession. When awarding a student a grade, LMEs reported that many sign-off mentors felt that grading practice gave them legitimacy to highlighting strengths and weaknesses of the student's achievements. There was a perception that signoff mentors were more discerning with practice grades reserving the higher grades for the outstanding student. Conversely, some participants noted that sign-off mentors were better able to identify struggling students through having a grading process.

Challenges were also highlighted such as the length of time it took to think about and write comments congruent with the grade being awarded, which sometimes led to lack of consistency between the grade and comments. Participants also commented that some sign-off mentors did not appreciate that terminology of level descriptors reflected the stage of the programme and were hesitant to award a higher grade when students were early on in their training. That said, in response to a question asking if there had been any noticeable difference in the students' grade profiles since grading practice had been introduced, half of the respondents $(n=20)$ suggested there had been some degree of grade inflation. This 
finding concurs with current evidence identifying that the majority of grades tend to cluster at the top of the grade scale (Edwards, 2012; Chenery-Morris, 2017). The HEls who did not notice a recent difference in practice grades had often been grading practice prior to 2009.

Concluding this phase of the project it was clear that there were inconsistencies in the interpretation and application of the NMC (2009) standards. It was acknowledged by the project team that complete alignment of documents was not expected due to the inevitability of innovation versus differing $\mathrm{HEI}$ regulations in developing curricula across the UK. However there was a view that some of the inconsistencies could be addressed in order to promote greater parity in how the NMC standards were applied as well as taking the opportunity to develop a set of principles to aid clarity, fairness and robustness for the student and sign-off mentor when practice was being assessed. These considerations fed into phase two of the project.

\section{Phase 2: Core principles for grading practice}

This phase of the study aimed to identify and agree a set of core principles for grading practice, aiding quality assurance and seeking to address concerns raised about subjectivity and grade inflation. The latter issue continues to be of national interest across all university programmes as the government seeks to address concerns over the growing number of firstclass degrees (The Guardian, 2018). The project group also wanted to improve assessment reliability by reducing the identified variations highlighted in table 1 . This phase of the study used participatory action research methodology (Freire, 1970; Denscombe, 2010). Data was collected via an on-line survey questionnaire followed by a group discussion with LMEs utilising a mini-Delphi approach (Green et al, 2007), to achieve consensus on terminology. Details of the design, data collection and results are reported by AUTHORS (2017b). Eleven core principles for grading midwifery practice were agreed (Table 2). The study findings recognised the importance of sign-off mentors being involved in developing the practice assessment tools (principle 2) and that clear verbal and written guidance on the assessment tool and the criteria for grading of performance / competence should be a requirement (principle 3). These two core principles have since been identified in the new NMC standards where all curricula need to be developed in partnership with relevant stakeholders (NMC, 2018c) and objective, evidence-based assessments must provide constructive feedback to facilitate professional development (NMC, 2018b:10).

\begin{tabular}{|l|l|}
\hline 1. The NMC requires clinical practice* to be assessed by clinicians with due regard. \\
\hline 2. Clinicians should be involved in developing and monitoring practice assessment tools/ \\
processes.
\end{tabular}


9. Specific grades or symbols should be awarded for clinical practice* rather than pass/ refer, reflecting a continuum of development and meeting requirements of the NMC Standards.

10. If a practice-based module includes elements other than clinical practice*, it is recommended that the credit weighting for these additional elements should not exceed $50 \%$ within that module.

11. Quality assurance of grading of practice (ie: monitoring of inter-rater reliability) should be undertaken collaboratively by academic staff and clinicians experienced in assessment.

Table 2 Core principles for grading practice in midwifery programmes (AUTHORS, 2017b)

"Reprinted from Nurse Education in Practice, 23 (March), AUTHORS, Core principles to reduce current variations that exist in grading of midwifery practice in the United Kingdom. Pages 54-60., Copyright (2017), with permission from Elsevier"

Phase 3: A generic framework for grading practice

The final phase of the project brought together findings of the previous two phases in order to develop a generic framework for grading midwifery practice using two proposed assessment tools devised by the project team: a 'Lexicon Framework' and 'Rubric' The Lexicon framework (Table 3 ) is a tool which comprises key words relevant for UK, undergraduate and postgraduate academic levels, which may be used to indicate levels of performance in practice. These were compiled according to the frequency of words used in existing midwifery practice assessment documentation across the UK. The Rubric (Table 4) comprises of sets of statements representing levels of performance in practice for UK undergraduate and postgraduate academic levels, mapped from the Lexicon Frameworks. One of each, at academic Level 5, is provided in Tables 3 and 4, with examples of their application. 


\begin{tabular}{|c|c|c|c|c|c|c|}
\hline LEVEL 5 & FAIL & PASS & GOOD & VERY GOOD & EXCELLENT & OUTSTANDING \\
\hline \multicolumn{7}{|l|}{ NOUNS } \\
\hline Knowledge & \multicolumn{6}{|c|}{ Key words: knowledge, evident(ce), understand(ing), inform (ed/ation), theory(etical), awareness, opinion, insight (ful), research } \\
\hline Skills & \multicolumn{6}{|c|}{ Key words: practice, able/ability, skill, care, act(ion/ive/ively), task, preparation, initiative, decision, competent (ce/ly) } \\
\hline Attitudes & \multicolumn{6}{|c|}{ Key words: behaviour, manner, compassion (ate), approach(able), philosophy, choice, perception, empathy (etic) } \\
\hline Other & \multicolumn{6}{|c|}{$\begin{array}{l}\text { Key words: woman, student, family, partner, colleague, NMC, time(s/ly), supervise(ion), standard, require(ment), midwife(ry), workload, support, resources, } \\
\text { situation, team, guidance, prompt, guideline, complication, range, }\end{array}$} \\
\hline \multirow[t]{2}{*}{ ADJECTIVES } & \multicolumn{6}{|c|}{ Key words: professional, direct, clinical, verbal, individual, own, verbal, written } \\
\hline & $\begin{array}{l}\text { unable } \\
\text { poor } \\
\text { insufficient } \\
\text { ineffective } \\
\text { inappropriate(ly) } \\
\text { inconsistent } \\
\text { unsafe(ly/ty) } \\
\text { little } \\
\text { limit(ed/ation) } \\
\text { unclear } \\
\text { inadequate } \\
\text { reticent, unwilling }\end{array}$ & $\begin{array}{l}\text { safe(ly/ty) } \\
\text { basic } \\
\text { essential } \\
\text { adequate } \\
\text { acceptable }\end{array}$ & $\begin{array}{l}\text { appropriate(ly) } \\
\text { accurate(ly) } \\
\text { significant(ce) } \\
\text { relevant } \\
\text { good } \\
\text { sound }\end{array}$ & $\begin{array}{l}\text { professional(s) } \\
\text { effective(ly) } \\
\text { clear(ly) } \\
\text { high } \\
\text { very good } \\
\text { confident(ce/ly) } \\
\text { responsive } \\
\text { sensitive(ly/ity) }\end{array}$ & $\begin{array}{l}\text { wide } \\
\text { excellent } \\
\text { complete(d) } \\
\text { proactive } \\
\text { different } \\
\text { positive(ly) } \\
\text { collaborative } \\
\text { motivated }\end{array}$ & $\begin{array}{l}\text { very } \\
\text { high } \\
\text { comprehensive(ly) } \\
\text { outstanding } \\
\text { complex } \\
\text { exceptional(ly) } \\
\text { reliable(ity) }\end{array}$ \\
\hline \multirow[t]{2}{*}{ VERBS } & \multicolumn{6}{|c|}{$\begin{array}{l}\text { Key words: show, document(ation), demonstrate(ion), develop(ment), respond, learn(er/ing), reflect(ive/ion), perform(ance), communicate(ion), lack, need(s) } \\
\text { apply(ication), manage(ment), provide, record, work, underpin, seek, make, identify }\end{array}$} \\
\hline & lacks & $\begin{array}{l}\text { begin(ning) } \\
\text { link }\end{array}$ & $\begin{array}{l}\text { participate } \\
\text { recognise (ition) } \\
\text { identify (ication) }\end{array}$ & $\begin{array}{l}\text { plans } \\
\text { prioritises } \\
\text { rationalise }\end{array}$ & $\begin{array}{l}\text { anticipate } \\
\text { evaluates }\end{array}$ & $\begin{array}{l}\text { modifiy (ication) } \\
\text { improves (ment) }\end{array}$ \\
\hline ADVERBS & & occasional(ly) & & & consistently & always \\
\hline
\end{tabular}

Table 3 Lexicon Framework example, academic level 5

Practice Assessment Toolkit @2019 AUTHORS 
Example 1: Johan demonstrates limited knowledge, however when asked, he can explain the rationale for the care he is giving using

evidence from NICE. He is unable to prioritise his workload and needs direct supervision at all times. He is professional in his interactions with women and their families but inconsistent in recording his findings.

Example 2: Estefania can plan and prioritise her workload; when the activity is high she is proactive in anticipating the requests of women for discharge, demonstrating awareness of the complex nature of maternity care. Her documentation is always completed to a high standard.

For a second-year student at level 5, Johan would refer or 'fail' in practice whereas Estefania would be awarded 'excellent'. 
Key: bold = high frequency, plain = medium frequency, italic = 'grammar words'

\begin{tabular}{|c|c|c|c|c|c|c|}
\hline Level 5 & FAIL & PASS & GOOD & VERY GOOD & EXCELLENT & OUTSTANDING \\
\hline Knowledge & $\begin{array}{l}\text { Unable to demonstrate } \\
\text { sufficient knowledge } \\
\text { and understanding to } \\
\text { underpin safe practice. }\end{array}$ & $\begin{array}{l}\text { Knowledge is } \\
\text { limited, but } \\
\text { adequate to inform } \\
\text { safe practice. }\end{array}$ & $\begin{array}{l}\text { Evidence of sound } \\
\text { knowledge and } \\
\text { understanding to } \\
\text { underpin safe practice. }\end{array}$ & $\begin{array}{l}\text { Evidence of very } \\
\text { good theoretical } \\
\text { knowledge which is } \\
\text { applied to practice. }\end{array}$ & $\begin{array}{l}\text { Demonstrates excellent } \\
\text { theoretical knowledge } \\
\text { which consistently } \\
\text { underpins practice. }\end{array}$ & $\begin{array}{l}\text { Outstanding evidence- } \\
\text { based knowledge is } \\
\text { consistently applied to } \\
\text { practice. }\end{array}$ \\
\hline Skills & $\begin{array}{l}\text { Limited ability to } \\
\text { perform common } \\
\text { clinical midwifery skills } \\
\text { and/or unsafe practice } \\
\text { is demonstrated. } \\
\text { Demonstrates } \\
\text { inadequate skills in } \\
\text { woman-centred, } \\
\text { compassionate care } \\
\text { and/or inappropriate } \\
\text { communication. }\end{array}$ & $\begin{array}{l}\text { Occasionally } \\
\text { demonstrates } \\
\text { limitations in some } \\
\text { clinical skills, but } \\
\text { ability is overall } \\
\text { satisfactory. } \\
\text { Student acts and } \\
\text { communicates } \\
\text { effectively in } \\
\text { providing } \\
\text { compassionate care } \\
\text { to the woman/ } \\
\text { family. }\end{array}$ & $\begin{array}{l}\text { Demonstrates good } \\
\text { ability in performance } \\
\text { of normal clinical } \\
\text { midwifery skills. } \\
\text { Able to provide } \\
\text { effective care, seeking } \\
\text { to meet the woman's } \\
\text { needs through } \\
\text { informed choice. }\end{array}$ & $\begin{array}{l}\text { Evidence of ability to } \\
\text { perform effective } \\
\text { clinical skills in a } \\
\text { range of situations. } \\
\text { Student } \\
\text { demonstrates very } \\
\text { good communication } \\
\text { skills to underpin } \\
\text { professional care and } \\
\text { team-work. }\end{array}$ & $\begin{array}{l}\text { Skilled in normal } \\
\text { clinical practice and is } \\
\text { developing the ability } \\
\text { to identify } \\
\text { complications under } \\
\text { supervision. } \\
\text { Demonstrates } \\
\text { evidence of excellent } \\
\text { professional } \\
\text { communication skills } \\
\text { and anticipation of } \\
\text { needs. }\end{array}$ & $\begin{array}{l}\frac{\text { Consistently }}{\text { outstanding }} \\
\text { performance of normal } \\
\text { clinical skills, responding } \\
\text { appropriately to risk. } \\
\text { Consistently cares for } \\
\text { women at a high } \\
\text { standard, demonstrating } \\
\text { outstanding } \\
\text { communication and } \\
\text { team-working skills. }\end{array}$ \\
\hline Attitudes & $\begin{array}{l}\text { Evidence of lack of } \\
\text { insight in the student's } \\
\text { understanding of } \\
\text { professional behaviour. } \\
\text { Student demonstrates } \\
\text { a poor attitude towards } \\
\text { guidance and feedback. }\end{array}$ & $\begin{array}{l}\text { Student } \\
\text { demonstrates } \\
\text { appropriate } \\
\text { professional } \\
\text { attitudes. } \\
\text { Student responds } \\
\text { appropriately to } \\
\text { guidance and } \\
\text { feedback. }\end{array}$ & $\begin{array}{l}\text { Student clearly } \\
\text { demonstrates a } \\
\text { professional approach } \\
\text { and compassionate } \\
\text { manner. } \\
\text { Student uses initiative } \\
\text { to self-assess and seek } \\
\text { appropriate support. }\end{array}$ & $\begin{array}{l}\text { Student's behaviour } \\
\text { and approach show } \\
\text { evidence of } \\
\text { appropriate } \\
\text { adaptability. } \\
\text { Student is competent } \\
\text { in reflective practice. }\end{array}$ & $\begin{array}{l}\frac{\text { Student demonstrates }}{\text { sensitivity to individual }} \\
\frac{\text { situations, showing } a}{\text { high level of insight. }} \\
\frac{\text { Student critically }}{\text { evaluates their own }} \\
\frac{\text { learning and }}{\text { development. }}\end{array}$ & $\begin{array}{l}\text { Student consistently } \\
\text { demonstrates sensitivity } \\
\text { and empathy in complex } \\
\text { situations. } \\
\text { Student consistently } \\
\text { analyses own } \\
\text { performance and } \\
\text { rationalises } \\
\text { modifications. }\end{array}$ \\
\hline $\begin{array}{l}\text { UNDER } \\
\text { MINIMAL } \\
\text { SUPERVISION: }\end{array}$ & $\begin{array}{l}\text { Does not achieve all the } \\
\text { NMC standards/ } \\
\text { requirements }\end{array}$ & $\begin{array}{l}\text { Achieves all the } \\
\text { NMC standards/ } \\
\text { requirements }\end{array}$ & $\begin{array}{l}\text { Achieves all the NMC } \\
\text { standards/ } \\
\text { requirements well }\end{array}$ & $\begin{array}{l}\text { Very good } \\
\text { achievement of all the }\end{array}$ & $\begin{array}{l}\text { Excellent achievement } \\
\text { of all the NMC }\end{array}$ & $\begin{array}{l}\text { Outstanding } \\
\text { achievement of all the }\end{array}$ \\
\hline
\end{tabular}




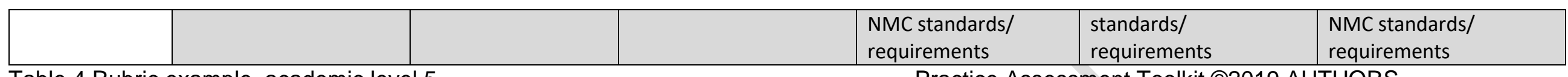

Table 4 Rubric example, academic level 5

Practice Assessment Toolkit (02019 AUTHORS

\section{EXAMPLES (please refer to above grid)}

\section{Example 1: Community}

Jade is compassionate and professional in her approach to women. She uses her initiative and seeks support appropriately. She demonstrates good clinical skills, for instance her abdominal examinations are almost always accurate in antenatal clinics. She shows sound knowledge to support her care.

Grade: Good

\section{Example 2: Antenatal ward}

Lizi has demonstrated outstanding knowledge about antenatal conditions such as pre eclampsia. She researches any condition she encounters and provides consistently outstanding evidence based care in complex situations. She is highly reflective of her own practice and evaluates her care, demonstrating sensitivity to individual situations and needs.

Grade: Outstanding 
The steps taken to develop the grading practice tool are reported on in more detail by AUTHORS (2019). From the available practice assessment documents used in 37 institutions (67.2\%) the frequency of words appearing in the assessment tools were ranked using 'Word Count Tool' (Word Counter, 2017). The words occurring most frequently were then transferred to a 'Lexicon Framework', where they were then converted to a range of generic statements. The statements related to knowledge, skills and attitudes were then ordered into appropriate descriptor levels forming the 'Rubrics'. The Lexicon Frameworks and Rubrics were then tested using an on-line survey targeted at midwifery and nursing students, clinicians and academics across the UK. The inclusion of nursing colleagues was deliberate in order to gauge the transferability of the assessment tools between professions. It was also important to determine if the tools were flexible enough to meet $\mathrm{HEl}$ preferences around areas such as awarding percentage grade $(70 \%, 60 \%, 50 \%$ etc) or letter (A, B, C, D etc) as well as to try and future proof as far as possible against up and coming changes in regulatory requirements.

Reports on findings from this final phase (AUTHORS, 2018; AUTHORS, 2019) highlight that the majority of feedback received from clinicians was positive. It was identified that the Lexicon Framework could be used as the primary tool for grading practice particularly when it came to writing evidence, with some suggesting it would enable more transparent and fairer grading. Students also responded positively remarking that they could use the Lexicon Frameworks and Rubrics to help self-assess their own practice. Areas for improvement included simplification of language and provision of examples to aid clarification. Feedback regarding the Rubrics suggested they could aid consistency of grading, even if the assessor had not worked predominantly with the student (as will be the case with the new NMC standards), and there was scope for transferability across professional programmes. Findings strongly supported introduction of a national assessment tool in both midwifery and nursing and many regions are working to develop these.

It was clear from the final phase of the study that there was an emphasis on the importance of learning and that both students and sign-off mentors need to understand and recognise achievement of performance in practice and that grading was only a small part of this. Therefore feedback to students of both their strengths and areas to develop, in a comprehensive and easily accessible format, should be the main focus, rather than the grade.

\section{Conclusion}

The initial aim of the project was to understand the similarities and differences between approaches to grading practice by HEls across the UK and identify if there could be a generic approach to aid consistency of assessment. The three phase project provided the underpinning evidence to develop a Practice Assessment Toolkit to ensure student assessments are evidence-based, robust and objective. The development of the toolkit is timely due to the NMC's recent publication of the standards for student supervision and assessment (NMC, 2018b), and so has particular relevance to practice supervisors and practice assessors on a daily basis when writing evidence to reflect performance of the student which can be objectively used by the assessor.

The Practice Assessment Toolkit can be found on the project website (AUTHORS, 2019). This comprises an explanation of its use, categories of levels of performance which may be relevant in a range of HEls, Wordles to provide visual representation of terms and the modified Lexicon Frameworks and Rubrics. 


\section{References}

Benner P (1984) From novice to expert. Addison-Wesley, California.

Bennett M, McGowan B (2014) Assessment matters-mentors need support in their role. $\mathrm{Br} \mathrm{J}$ Nurs 23 (9): 454-458.

Chenery-Morris S (2017) Grading student midwives' practice: a case study exploring relationships, identity and authority. UEA unpublished PhD.

Denscombe M (2010) Good Research Guide: For small-scale social research projects. 4th edn. Open University Press, Berkshire.

Donaldson J, Gray M (2012) Systematic review of grading practice: is there evidence of grade inflation? Nurse Educ Pract 12: 101-114. https://doi.org/10.1016/j.nepr.2011.10.007 (accessed 18 December 2018).

Edwards A (2012) Grading practice: an evaluation one year on. Nurse Educ Today 32(6), pp. 627-629. https://doi.org/10.1016/i.nedt.2012.04.018 (accessed 18.12.18).

AUTHORS (2017a) A scoping study to explore the application and impact of grading practice in pre-registration midwifery education across the United Kingdom. Nurse Educ Pract 24: 99105. https://doi.org/10.1016/..nepr.2016.01.007

AUTHORS (2017b) Core principles to reduce current variations that exist in grading of midwifery practice in the United Kingdom. Nurse Educ Pract 23: 54-60.

https://doi.org/10.1016/j.nepr.2017.02.006

AUTHORS (2018) National Grading of Practice in Pre-registration Midwifery Project: https://www.plymouth.ac.uk/research/national-grading-of-practice-in-pre-registrationmidwifery-project (accessed 18 December 2018)

AUTHORS 2019. National Survey: Developing a Common Approach to Grading of Practice in Pre-registration Midwifery. Nurse Educ Pract, 34: p150-160.

https://doi.org/10.1016/j.nepr.2018.11.014 (accessed 18 December 2018)

Freire P (1970) Pedagogy of the Oppressed. Herder \& Herder, New York.

Gray MA, Donaldson J (2009) Exploring issues in the use of grading in practice; literature review. Edinburgh Napier University, Edinburgh.

Green K.C, Armstrong J.S and Graefe A (2007) Methods to Elicit Forecasts from Groups: Delphi and Prediction Markets Compared. Munich Personal RePEc Archive.

https://mpra.ub.uni-muenchen.de/4663/1/MPRA paper 4663.pdf (accessed 18 December 2018).

Heaslip V, Scammell J (2012). Failing underperforming students: The role of grading in practice assessment. Nurse Educ Pract 12: 95-100.

https://doi.org/10.1016/i.nepr.2011.08.003 (accessed 18 December 2018).

Nursing and Midwifery Council (2008) Standards to support learning and assessment in practice. NMC, London.

Nursing and Midwifery Council (2009) Standards for pre-registration midwifery education. NMC, London.

Nursing and Midwifery Council (2018a) The Code: Professional standards of practice and behaviour for nurses, midwives and nursing associates. NMC, London. 
Nursing and Midwifery Council (2018b) Realising professionalism. Part 2: Standards for student supervision and assessment. NMC, London.

Nursing and Midwifery Council (2018c) Realising professionalism. Part 1: Standards framework for nursing and midwifery education. NMC, London.

NHS Commissioning Board (2012) Compassion in practice. Nursing and midwifery care staff: our vision and strategy. Department of Health, England.

Steinaker N and Bell R (1979) The experiential taxonomy. Academic Press, New York.

The Guardian (2018) UK universities face grade inflation crackdown.

https://www.theguardian.com/education/2018/oct/22/uk-universities-face-grade-inflationcrackdown (accessed 18 December 2018)

Word Counter (2017) Word Counter - Word Count Tool. https://wordcounttools.com/ (accessed 18 December 2018). 